\title{
STUDENTS’ DIFFICULTIES IN TRANSLATING NARRATIVE TEXT FROM ENGLISH INTO INDONESIA AT GRADE VIII OF SMP NEGERI 9 PEMATANGSIANTAR \\ Basariya Pasaribu $^{1}$, Herman $^{2}$, David Togi Hutahaean ${ }^{3}$ \\ 1,2,3 Universitas HKBP Nommensen (UHN), Medan, Indonesia \\ basariyapasaribu18@gmail.com ${ }^{1}$, herman@uhn.ac.id², davidhutahaean138@gmail.com³
}

\begin{abstract}
This research was intended to find out kinds of students difficulties in translating narrative text from English into Indonesia of SMP Negeri 9 Pematangsiantar. Therefore, the researcher formulated a question as the problem. As follows: "What are the students difficulties in translating narrative text from English into Indonesia of SMP Negeri 9 Pematangsiantar?" The researcher was used qualitative design. To answer the problem, the researcher used grade eight students of SMP Negeri 9 Pematangsiantar as the population and used 31 students as the sample, they were VIII-1. The instrument of the research of this research was narrative text. The data were collected by using record video of mobile phone then to be analyzed the result of students' translation and correction. The research finding showed that students were difficulties in translating narrative text from English into Indonesia. The highest number of students' difficulty is tense $(32 \%)$. The second most difficulties faced by students is sentence $(25,4 \%)$. The third difficulty is phrase $(16,6 \%)$. The fourth is clause $(15,4 \%)$. The fifth difficulty is attribute $(8,2 \%)$ and the last is indefinite article $(2,4 \%)$. It can be concluded that students have difficulties in translating narrative text from English into Indonesia is tense, not sentence, phrase, clause, attribute, and indefinite article.
\end{abstract}

Keywords: article; difficulties, English, narrative, translation

\section{INTRODUCTION}

Language is a complex system of communication that used human beings. By language we can talk with other people, can give information, can able to exchange knowledge, can express emotion, ideas, beliefs, feelings, opinions, wishes, thanks, and promises. Fernandez and Helen (2011:6) stated that language is primary communication system for human beings, but it is not the only way to communicate, so language can be distinguished from communication in general. Many forms of communication are not linguistics; these include non-verbal, mathematical, and aesthetic communication through music or the visual arts. Vyvyan (2014:1) 
stated that language is central to our lives, the cultural tool that arguably sets us apart from other species. Central in our life is communication with other people, to socialization with society, and culture. Therefore, the researcher concludes that language is a device of communication.

To communicate, there are many kinds of languages in the entire world, such as Indonesia, South Korea, Mandarin, Javanese, English etc. From many languages which are used by the people, one of them is English. Crystal (2003:1) stated that English is the global language. The global era is develop in the world, many country used English as a tool of communication and it makes people who come from different countries to be easier in making interaction and communication. This is indicating to the world that English is important to learn including in Indonesia.

In Indonesia, English is a foreign language which the students must be mastered of the global language. To master it, the government conclude that English become part of curriculum of the school be taught to the student. The students should master the four skills such as listening, speaking, reading, and writing. Writing is a tool of communication in written form. Tillema (2012:1) stated that writing is one of the most important skills for educational success, but also one of the most complex skills to be mastered. In doing writing skill, especially in translation the researcher must be able to translate the translation based on mind. In Indonesia, many text written in English that use by Restaurant, Hospital, Hotel and some of places for that Indonesian people need to translate of the text to known and get information or instruction.

According to Catford (1965) in Herman (2017:73) defines translation as "the replacement of textual material in one language (SL) by equivalent textual material in another language (TL). It means that when we translate a text to another language, we just change the language of the text itself to the language we want to translate without changing meaning of the SL. Herman (2016:9) stated that translation is known as the process of transferring one language (known as Source Language) to another language (known as Target Language). As we know translation is a process transfer of meaning from source language (SL) into target language (TL). In translating English into Indonesia the students should be able to translate the sentence from source language (SL) to target language (TL).

The process of translation there are problems that faced by some of people. The problems of translation are difficulties which make us stop translating to think about it. Difficulties in translating that often faced almost by people can be of multiple causes; it can be grammatical, lexical, and cultural. According to Silviana (2008:1), difficulties in translating are when someone who translates the text, but does not understand how to use adverb, verb, noun so that the 
sentences are not perfect. To translate the sentence perfectly, the students should have many vocabularies and understand about grammatical structure. The grammatical structure is always one of the problems that a lot of learners face in doing translation. In previous research done by Hadrus (2017:17), she stated that there are four general categories of students difficulties in translation such as; difficult to understand the meaning of word that not find in dictionary, difficult to translate the idiomatic phrases and collide with culture, difficult to translate the long and complex sentence, and difficult to arrange the text in target language. So the problems in translation can be divided in two problems, they are: linguistic problem and culture problem. Linguistic problem involves grammar, different vocabulary, and the meaning of each word. In this research, the researcher will focus to linguistic problem. Based on the reference from the previous research above, the researcher also had the same experience when doing teaching practice in SMP Negeri 9 Pematangsiantar. In the process of translating, the researcher found that the problems of the students when they studied of English, especially, in translating the sentence.

In general, the students' problems in form translation, example: The students translated the sentence word by word. Between some of the students, the students often translated the sentence word by word, for example: (SL:She likes to drink orange juice) the result of students translation (TL: Dia suka ke minum jus jeruk) the students always translated the sentence word by word and the students can not able to arranged of the sentence. While in English it is not all sentence can be translate word by word. Because, each sentence contained an ambiguous words which multiple meanings. And also when the students translate of the sentences use dictionary, the students often just see the first meaning from each word when they opend dictionary. That we know each words have many of meaning in a dictionary, for example: (SL: Harvey have studied two foreign languages) the result of students translation (TL: Harvey memiliki belajar 2 bahasa) the target language has not a meaning. Based on the sentence above the sudents translation 'have' be 'telah'. We know that 'have/has meaning in Indonesia such as: telah, sudah, semoga, mempunyai, and mengalami etc, but the students use the first meaning without use structure and see the contextually. In the case of problem the students above, the researcher conclude that the students have problems in grammatical problem. To analyze it, the researcher will use narative text as they learned based on the curriculum. Besides that, the reason of the researcher choose narrative text, because narrative text is tell about the legend which the story is more interesting that can make of the students like to translate the story. 
Herman (2014:31) stated that narrative text isintroduced to amuse or entertain thereaders with actual or imaginary experience in differentways. In this occasion, the researcher would like to analyze the students' difficulties in translating of the text, especially in translating narrative text from English into Indonesia entitled, 'Students' Difficulties in Translating Narrative Text from English into Indonesia at Grade VIII of SMP Negeri 9 Pematangsiantar”.

\section{METHOD}

\section{A. Research Design}

This research is considered as qualitative research. This research uses qualitative method because it conducts to describe situation, events, or occurrences of the basic data. Creswell (2014:4) stated that qualitative research is a research for exploring and understand the meaning individuals or groups a scribe to social or human problem. That is to say, it aims to help us to understand the social world in which we live and why things are the way they are. In this study, the researcher uses an observation to analyze what the student's difficulties in grammatical problems of students' translation. Hence, Hancock \& Ockleford (2009:18) stated that observation is a technique that can be used when data cannot be collected through other means, or those collected through other means are of limited value or are difficult to validate.

\section{B. Subject of Research}

Subject of research is the students of grade VIII in SMP Negeri 9 Pematangsiantar. The total numbers of students are 341 students of 11 classes. The researcher chooses VIII-1 that consists of 31 students as subject of the research.

\section{Object of the Research}

The object of the research is the students' result in translating narrative text from English into Indonesia by students at grade eight of SMP Negeri 9 Pematangsiantar.

\section{Instrument of the Research}

The researcher used Samsung Galaxy J1 (2016) mobile phone as a tool to record video in activity of research. The researcher uses two texts of narrative text as they learn based on curriculum which one text will be translated by at least 15 students from their seat. The students will read the text before to translate the text. After that the students will translate the text in the paper while researcher will collecting the result of students translate to analyze of the data.

\section{E. Technique of Data Collection}

Cohen \& Lawrence (2007:315) stated that collecting data is how they can be used, and how they can be constructed,

In collecting the data, the researcher uses some steps: 
1. Giving a narrative text to students

2. Asking the students to translate the narrative text

3. Collecting and taking a picture of the result of students by Samsung Galaxy J1(2016) mobile phone.

\section{F. Technique of Data Analysis}

Cohen \& Lawrence (2007) stated that qualitative data analysis involves organizing, accounting for and explaining the data; in short, making sense of data in terms of the participants' definitions of the situation, noting patterns, themes, categories and regularities.

In analyzing the data, the researcher uses some steps:

1. Reading to the result of students translating

2. Transcribing of the data into grammatical problems

3. Classifying the data into grammatical problems of translation

4. Drawing a finding based on the students problem of translation

5. Interpreting the findings.

\section{FINDING AND DISCUSSION}

After analysis the data of students translation result, the researcher had found some of students' difficulties in translating narrative text from English into Indonesia in grammatical problems. The percentage can be seen as follows:

Table 3.1.Percentage of Students' Difficulties in Translating Narrative text from English into Indonesian.

\begin{tabular}{|c|c|c|c|}
\hline NO & $\begin{array}{c}\text { Types of Grammatical } \\
\text { Problems }\end{array}$ & Total Problems & $\begin{array}{c}\text { Total } \\
\text { percentage }\end{array}$ \\
\hline 1 & Phrase & 28 & $16,6 \%$ \\
\hline 2 & Clause & 26 & $15,4 \%$ \\
\hline 3 & Tense & 54 & $32 \%$ \\
\hline 4 & Sentence & 43 & $25,4 \%$ \\
\hline 5 & Attribute & 14 & $8,2 \%$ \\
\hline 6 & Indefinite Article & 4 & $2,4 \%$ \\
\hline
\end{tabular}

From the table 3.1 above, it can be concluded that students difficulties in translating narrative text from English into Indonesia, the most frequent difficulties which students made is tense. The highest number of students' difficulty is tense (32\%). The second most difficulties faced by students is sentence $(25,4 \%)$. The third difficulty is phrase $(16,6 \%)$. The fourth is clause $(15,4 \%)$. The fifth difficulty is attribute $(8,2 \%)$. And the last is indefinite article $(2,4 \%)$. 
Based on the data analysis and finding, the researcher would like to discuss the findings in this research with the research done by previous research, Hadrus (2017) in her research entitled "The Analysis of Students Difficulties in Translating Argumentative text at the Second Grade Students of SMA Negeri 1 Lappariaja". Based on the data analysis, the researcher found that the students' difficulties in translating argumentative text were the difficulties in linguistics factors more prominent than non-linguistics factors. This was proven by the highest percentage of students difficulties was $75 \%$ in linguistic factor. And 66,67\% the highest percentage of students difficulties in non-linguistics factor. The conclusion that can be drawn in this research is there is a similar finding in this research with Hadrus'. The similarity lies on the students' difficulties in translating from the linguistics factors such as the tenses, vocabulary and so on. Therefore, it does not matter whether what kinds of texts are selected as the text to be selected, the results show that the grammatical problems are to be the main factors that should be given more attention in translating text from source language to target language.

\section{CONCLUSION}

After describing students' difficulties in translating narrative text from English into Indonesia found in the students' worksheet, the researcher conclude that found some difficulties in translating narrative text from English into Indonesia such as the equivalent meaning in tense from translating narrative text from English into Indonesia; it can be seen from percentage of students mistake about $32 \%$ in tense. Based on the conclusion above this study show that various ways in translating are provided to the translator to achieve accurateness, the equivalence, and made the translation is acceptable.

\section{REFERENCES}

Creswell, J. W. (2014). Research Design: Qualitative, Quantitative, and Mixed Methods Approaches. Fourth Edition. California: Sage, ISBN-978-1-4522-2610-1 (pbk.)

Crystal, D. (2003). English as a Global Language. Second Edition. New York:Cambridge University Press, ISBN-10-0-521-53032-6- Paperback

Fernandez, E. M \& Helen, S. C. (2011). Fundamental of Psycholinguistics. Singapore: British Library, ISBN-978-1-4051-9152-4

Hadrus, M. S. (2017). The Analysis of Students Difficulties in Translating Argumentative Text from English to Indonesia at The Second Grade Students of SMA Negeri 1 Lappariaja Bone

Regency. 
(Online), http://repositori.uinalauddin.ac.id/8227/1/MEI\%20SAKRIANI\%20HADRUS.pd $\underline{f}$, accessed on April $\left.6^{\text {th }} 2019\right)$

Hancock, B.\& Ockleford, E. (2009). An Introduction to Qualitative Research. Nottingham: University of Nottingham.

Herman. (2014). An Experiential Function on Students' Genre of Writing. Jakarta: Halaman Moeka

Herman. (2016). The Method of Translation and practices. Deutschland/Germany: LAP Lambert, ISBN-978-3-330-00145-9

Herman. (2017). Shift in Translation from English into Indonesia on narrative text. International Journal of European Studies, Vol. 1, No. 3.

Silviana, E. (2008). An Analysis of Students Difficulties in Translating Narrative Text.(Online), (https://id.scribd.com/document/344032322/Students-Difficulties-in-TranslatingNarrative-Text, accessed on April $26^{\text {th }} 2019$ )

Tillema, M. (2012). Writing in first and second language Empirical studies on text quality and writing processes. The Netherlands: http://www.lotschool.nl, ISBN: 978-94-6093-082-9

Vyvyan, E. (2014). The Language Myth. United Kingdom: Cambridge 